\title{
Molecular cloning and expression of a putative crustacean hyperglycemic hormone of Litopenaeus vannamei in Pichia pastoris
}

\author{
Edna Sánchez-Castrejón \\ Departamento de Biotecnología Marina \\ Centro de Investigación Científica y de Educación Superior de Ensenada \\ Km 107 Carretera Tijuana-Ensenada, Ensenada B. C., 22860, México \\ Tel: 526461750500 \\ Fax: 526461750569 \\ E-mail: esanchez@cicese.mx \\ Elizabeth Ponce-Rivas* \\ Departamento de Biotecnología Marina \\ Centro de Investigación Científica y de Educación Superior de Ensenada \\ Km 107 Carretera Tijuana-Ensenada, Ensenada B. C., 22860, México \\ Tel: 526461750500 \\ Fax: 526461750569 \\ E-mail: eponce@cicese.mx \\ Manuel B. Aguilar \\ Laboratorio de Neurofarmacología Marina \\ Instituto de Neurobiología, Universidad Nacional Autónoma de México, Campus Juriquilla \\ Blvd. Juriquilla 3001, Juriquilla, Qro., 76230, México \\ Tel/Fax: 524422381043 \\ E-mail: maguilar@servidor.unam.mx \\ Fernando Díaz \\ Departamento de Biotecnología Marina \\ Centro de Investigación Científica y de Educación Superior de Ensenada \\ Km 107 Carretera Tijuana-Ensenada, Ensenada B. C., 22860, México \\ Tel: 526461750500 \\ Fax: 526461750569 \\ E-mail: fdiaz@cicese.mx
}

Financial support: This work was supported by Consejo Nacional de Ciencia y Tecnología (CONACyT) through a fellowship to E. Sánchez-Castrejón.

Keywords: CHH, Litopenaeus vannamei, Pichia pastoris, recombinant protein.

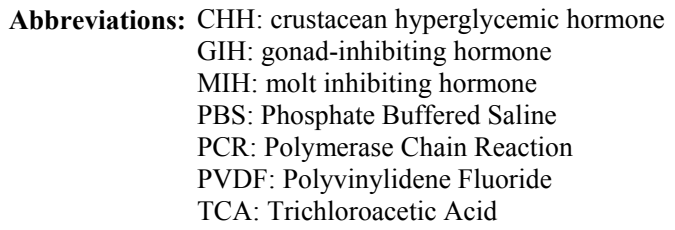

Crustacean hyperglycemic hormone (CHH) is the most abundant and best studied member of the CHH/MIH/GIH neuropeptide hormone family. CHH plays a major role in controlling glucose levels in the hemolymph, and it also has significance in regulating molting, reproduction, and osmoregulation. In contrast, molt-inhibiting hormone (MIH) is responsible for maintaining animals in an intermolt stage. In this study, Liv-MIH-1 cDNA, which encodes a mature neuropeptide from the eyestalk of white shrimp, Litopenaeus vannamei, was expressed in methylotrophic yeast (Pichia pastoris KM71) under the control of an alcohol oxidase promoter. Recombinant Liv-MIH-1 was secreted into the culture medium using the $\alpha$-factor prepro-sequence without Glu-Ala repeats. The expected protein, which had an apparent molecular mass of 12.1 kDa, was detected by Tricine-SDS-PAGE analysis and confirmed by Western blot. Pure recombinant LivMIH-1 was obtained by affinity chromatography, and $\mathrm{N}$-terminal sequence analysis confirmed expression of the protein. Biological assays for $\mathrm{CHH}$ and MIH activity were also performed. Purified recombinant Liv-MIH-1 showed the ability to elevate the glucose level of hemolymph of L. vannamei, but molting was unaffected. Since these results are in agreement with the high structural and phylogenetic similarity that has been

*Corresponding author 
observed between Liv-MIH-1 and other CHH neuropeptides we propose to rename the protein LivCHH-SG1.

The X-organ sinus gland (XOSG) complex, located in the optic ganglia in the eyestalk, is the major neuroendocrine control center of crustaceans. Among the eyestalk peptides, crustacean hyperglycemic hormone $(\mathrm{CHH})$ is the most abundant and the best studied. $\mathrm{CHH}$ is a member of a structurally related peptide family, which also includes molt-inhibiting hormone (MIH), gonad-inhibiting hormone $(\mathrm{GIH})$ and mandibular organ-inhibiting hormone $(\mathrm{MOIH})$ (Böcking et al. 2001). This peptide family plays important roles in controlling several physiologic processes such as regulation of growth and reproduction. $\mathrm{CHH}$ is involved mainly in the regulation of glucose levels in the hemolymph, as well as in the metabolism of carbohydrates and lipids, molt, reproduction and osmoregulation (Yasuda et al. 1994; Santos et al. 1997; Khayat et al. 1998; Serrano et al. 2003), while MIH is one of the major keys in mediating growth and reproduction (Webster and Chung, 1999; Sonobe et al. 2001). Neuropeptide members of the $\mathrm{CHH}$ family are difficult to study because they are synthesized in small quantities and the similarities in size and primary structure to other eyestalk neuropeptides limit their isolation and purification. DNA recombinant technology is useful in generating these crustacean peptides in sufficient quantities to enable further study of their physiological roles and structure-activity relationships.

$\mathrm{CHH}$ and $\mathrm{MIH}$ recombinant proteins have been successfully expressed in Escherichia coli, but they were aggregated in an insoluble form (Ohira et al. 1999; Gu et al. 2000; $\mathrm{Gu}$ et al. 2001; $\mathrm{Gu}$ et al. 2002). However, a Eukaryotic expression system offers advantages since solubilization and refolding are not necessary for the production of biologically active neurohormones. The methylotrophic yeast, Pichia pastoris, is attractive for expressing shrimp proteins due to its relatively simple expression methods for the secretion of recombinant proteins (Sun, 1997; Udomkit et al. 2004; Yodmuang et al. 2004). This methylotrophic yeast system can secrete high levels of a wide variety of heterologous proteins using the Sacharomyces cerevisiae $\alpha$-factor prepro-sequence (Cereghino and Cregg, 2000). Additionally, Glu-Ala repeats enhance the activity of the Kex2 protease when the $\alpha$-factor secretion signal is used (Raemaekers et al. 1999).

Five different cDNA sequences encoding MIH (Sun, 1994; Chen et al. 2007; Lago-Lestón et al. 2007) and one cDNA sequence encoding CHH (Lago-Lestón et al. 2007) have been reported in Litopenaeus vannamei, one of the most important cultured shrimp species in Latin America. The cDNA encoding Liv-MIH-1 has been cloned and sequenced recently by our group (Lago-Lestón et al. 2007). The gene was amplified using primers designed from the mih cDNA sequence reported by Sun (1994). However, structural and phylogenetic analysis suggested that Liv-MIH-1 may have $\mathrm{CHH}$ activity or have a multi-functional role as observed in other CHH family members (Chang et al. 1990; Sefiani et al. 1996; Lago-Lestón et al. 2007). Liv-MIH-1 was previously produced as a mature peptide in Pichia pastoris (data not published). However, the Glu-Ala repeats at the $\mathrm{C}$-terminus of the $\alpha$-factor prepro-sequence were not efficiently removed, resulting in polypeptides with heterogenous $\mathrm{N}$-termini still containing $\mathrm{N}$-terminal extensions. Incorrect processing of Glu-Ala repeats by the Ste13 aminopeptidase has been observed in other studies (Briand et al. 1999; Raemaekers et al. 1999). The present study, therefore, involves the construction and expression of a plasmid that contains the cDNA encoding Liv-MIH-1 peptide in $P$. pastoris using the $\alpha$-factor prepro-sequence without Glu-Ala repeats. Additionally, the c-myc epitope, 6XHis tag, and enterokinase recognition sites were included at the C-terminus, for antibody detection, purification, and the possibility of subsequent elimination of the extra amino acids from the C-terminus of the recombinant Liv-MIH-1, respectively. SDS-PAGE, Western blot, and N-terminal peptide sequencing analyses confirmed the successful expression and $\mathrm{N}$-terminal processing of the secreted protein. The biological assays for $\mathrm{CHH}$ and $\mathrm{MIH}$ activities of the recombinant Liv-MIH-1 are also described in this report.

\section{MATERIALS AND METHODS}

\section{Materials}

E. coli TOP 10F' and P. pastoris KM71 strains (Invitrogen, Carlsbad, CA, USA) were used for plasmid construction and expression, respectively. Recombinant Taq DNA polymerase, Zeocin, pPICZ $\alpha A$ expression vector, EnterokinaseMax (EKMax) and the ProBond Purification system were purchased from Invitrogen; T4 DNA ligase was from Roche (Indianapolis, IN, USA), and media components were from BD (Franklin Lakes, NJ, USA). Broad Range Protein Molecular Weight Marker was from Promega (Madison, WI, USA).

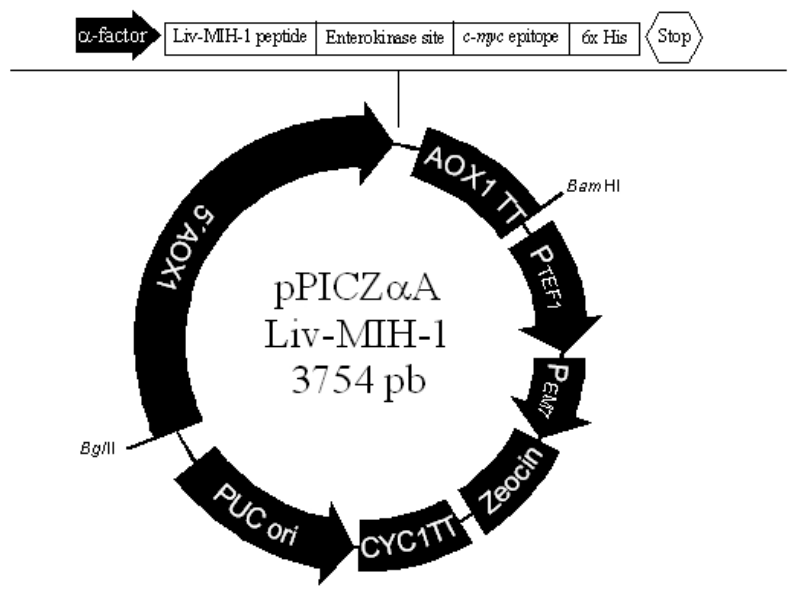

Figure 1. Map of pPICZaA-Liv-MIH-1. 


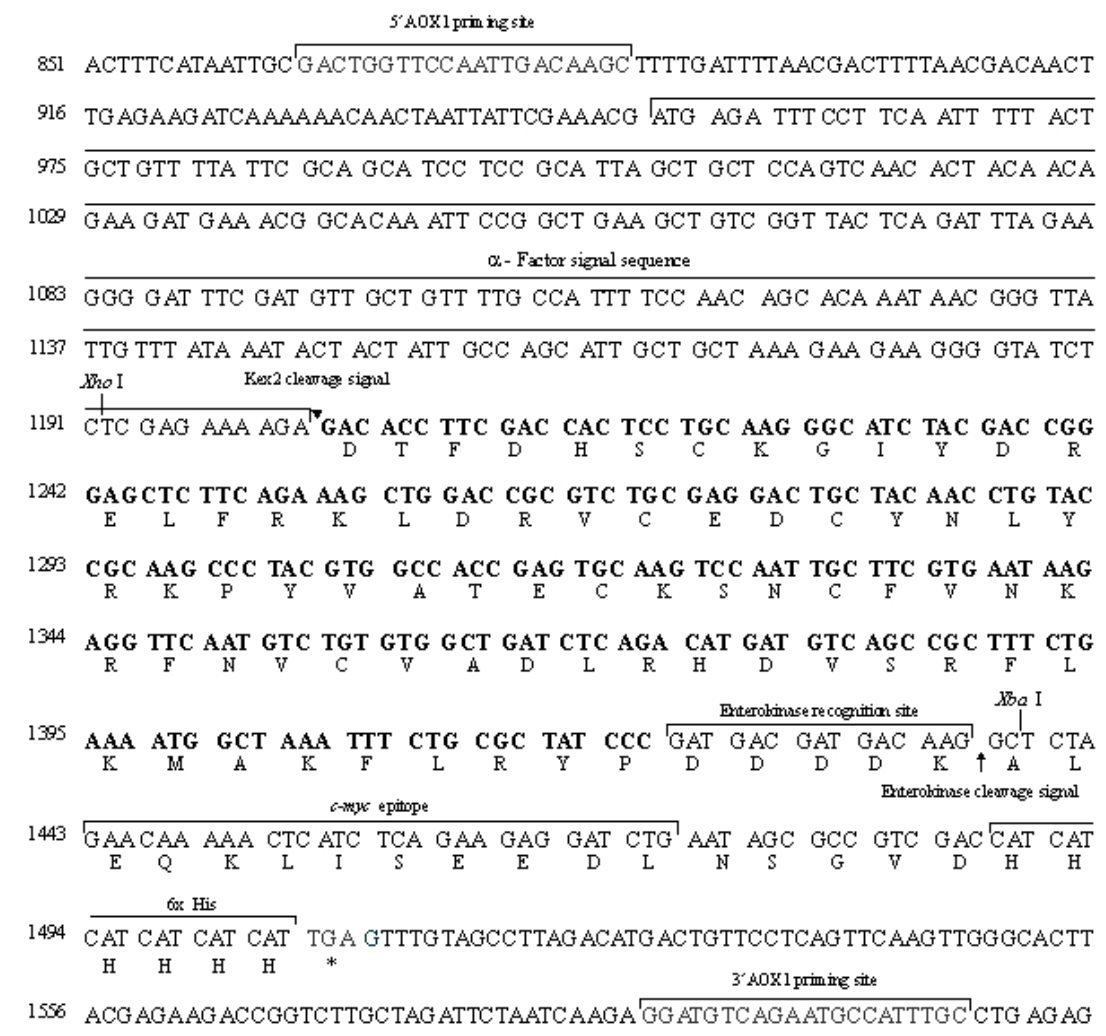

Figure 2. Nucleotide and deduced amino acid sequence of Liv-MIH-1. The mature Liv-MIH-1 peptide is bolded. The asterisk marks the termination codon.

\section{Construction of the expression vector}

The cDNA sequence encoding to the mature MIH peptide was amplified by PCR using primers that included the XhoI and $X b a I$ sites and the enterokinase recognition site. The primers were: F1: 5'CCGCTCGAGAAAA GAGACACCTTCGACCACTCCTGCAAGG3', R1: 5'GCTCTAGAGCCTTGTCATCGTCATCGGGATAGCG CAGAAA3'. The template was the recombinant plasmid clone pBAD-MIH. The PCR conditions were: initial denaturing at $94^{\circ} \mathrm{C}$ for $3 \mathrm{~min} ; 30$ cycles of $45 \mathrm{sec}$ at $94^{\circ} \mathrm{C}$, $30 \mathrm{sec}$ at $55^{\circ} \mathrm{C}, 30 \mathrm{sec}$ at $72^{\circ} \mathrm{C}$; final extension at $72^{\circ} \mathrm{C}$ for $10 \mathrm{~min}$.

The amplified fragment of Liv-MIH-1 was digested with $X h o I$ and $X b a \mathrm{I}$ and ligated into the corresponding restriction sites in the pPICZ $\alpha \mathrm{A}$ vector according to the manufacturer's protocol (Figure 1). Competent E. coli cells were transformed with the ligation product (pPICZ $\alpha$ A-LivMIH-1) by electroporation, and transformants were selected in low salt Luria Bertani plates that contained $25 \mu \mathrm{g} / \mathrm{ml}$ Zeocin. The plasmid vector construction was verified by sequencing (SeqxCel, San Diego, CA, USA) using 5'AOX1 and 3'AOX1 primers (Invitrogen). The pPICZ $\alpha A-L i v-$ MIH-1 vector was linearized with BstXI and introduced into
P. pastoris KM71 by electroporation, as described in the manual (Version G) of the EasySelect Pichia Expression Kit (Invitrogen). The transformants were selected on YPDS plates (1\% yeast extract, $2 \%$ peptone, $2 \%$ dextrose, $1 \mathrm{M}$ sorbitol, 2\% agar) that contained $100 \mu \mathrm{g} / \mathrm{ml}$ Zeocin and verified by colony PCR and sequencing analysis.

\section{Expression of recombinant pPICZaA-Liv-MIH-1}

A fresh, single colony of $P$. pastoris carrying pPICZ $\alpha \mathrm{A}$ Liv-MIH-1 was grown in $3 \mathrm{ml}$ of YPD medium ( $1 \%$ yeast extract, $2 \%$ peptone, $2 \%$ dextrose) with $100 \mu \mathrm{g} / \mathrm{ml}$ Zeocin and incubated for $24 \mathrm{hrs}$ at $30^{\circ} \mathrm{C}$ and $300 \mathrm{rpm}$. The culture was transferred into $100 \mathrm{ml}$ of BMGY medium (1\% yeast extract, $2 \%$ peptone, $0.67 \%$ Yeast Nitrogen Base (YNB), 4 $\mu \mathrm{g} / \mathrm{ml}$ D-biotin, $100 \mathrm{mM}$ potassium buffer $\mathrm{pH} 6.0,1 \%$ glycerol) and incubated under the same conditions. When the $\mathrm{OD}_{600}$ of the culture reached 5 , the cell culture was concentrated 5 times by centrifugation (2000 × $g$, $5 \mathrm{~min}$ ). To determine the optimal conditions for Liv-MIH-1 expression, the $P$. pastoris pellet was resuspended in $20 \mathrm{ml}$ of BMMY medium ( $1 \%$ yeast extract, $2 \%$ peptone, $0.67 \%$ YNB, $4 \mu \mathrm{g} / \mathrm{ml}$ D-biotin, $100 \mathrm{mM}$ potassium buffer $\mathrm{pH} 6.0$ ) with various concentrations of methanol $(0,1,2$ and 4\%) and monitored for 6 days. Fresh methanol was added daily 

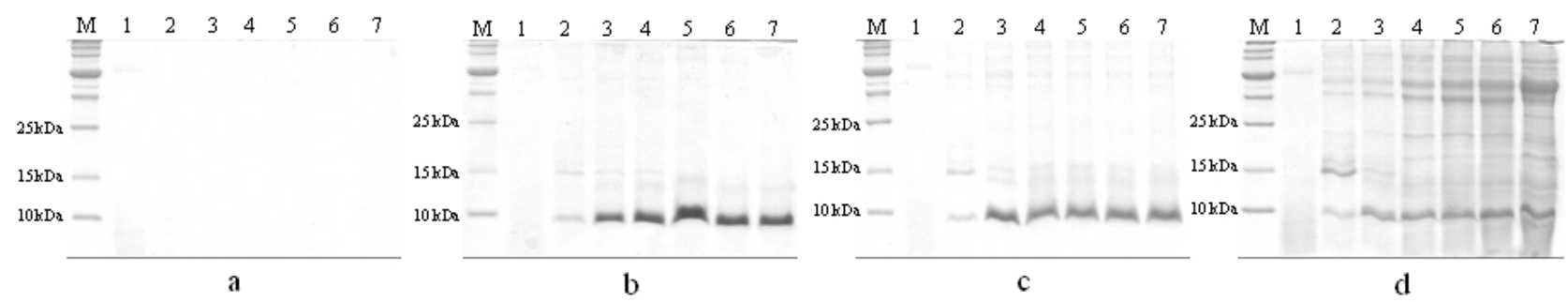

Figure 3. Analysis of recombinant Liv-MIH-1 protein expression in $P$. pastoris by Coomassie-stained-Tricine-SDS-PAGE. M: Broad Range Protein Molecular Weight Marker (Promega). Gels represent expression in different concentrations of methanol: a) $0 \%$; b) $1 \%$; c) $2 \%$ and d) $4 \%$. Lanes 1 to 7 correspond to day of induction (0-6).

to maintain induction. Every day, $1 \mathrm{ml}$ aliquots of the expression cultures were collected; the samples were centrifuged $\left(2000 \times \mathrm{g}, 5 \mathrm{~min}, 4^{\circ} \mathrm{C}\right)$, and the supernatants were recovered and stored at $-20^{\circ} \mathrm{C}$ for further analysis.

\section{Tricine-SDS-PAGE and Western blot analysis}

The expression of the recombinant Liv-MIH-1 was analyzed by Tricine-SDS-PAGE (16.5\%) according to the method of Schägger (2006). The secreted product was concentrated by TCA precipitation, resuspended in $20 \mu \mathrm{l}$ of sample buffer, and heated in boiling water for $10 \mathrm{~min}$ before loading onto gel. The bands were visualized by staining with Coomassie Brilliant Blue R-250.

The presence of the recombinant Liv-MIH-1 was confirmed by Western blot analysis. The protein samples in the gel were transferred to a $0.45 \mu \mathrm{m}$ Trans-Blot Transfer Medium nitrocellulose membrane (BioRad, Hercules, CA, USA)

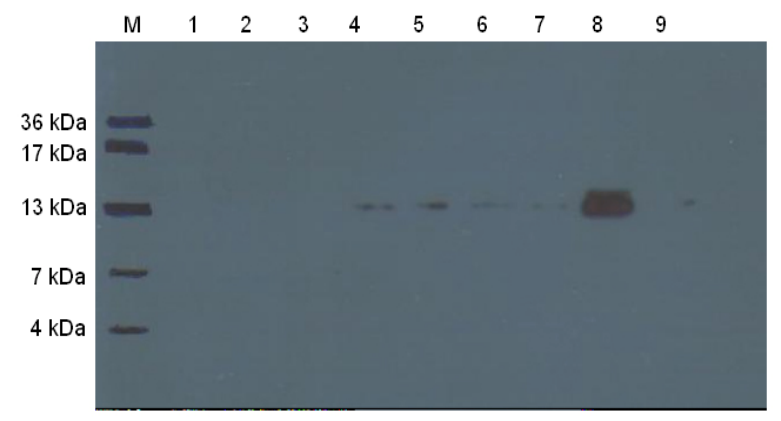

Figure 4. Analysis of recombinant Liv-MIH-1 protein expression in $\boldsymbol{P}$. pastoris by Western blot. M: MultiMark Multicolored Standard (Invitrogen). Lanes 1 and 2 correspond to cultures induced with $2 \% \mathrm{MeOH}$ : Lane 1, KM71; Lane 2, $\mathrm{KM} 71+\mathrm{pPICZ} \alpha \mathrm{A}$ without insert. Lane 3 corresponds to noninduced Liv-MIH-1. Lanes 4 and 5 correspond to Liv-MIH-1 induced with $0.5 \% \mathrm{MeOH}$ : Lane 4 , day 1; Lane 5 , day 2 . Lanes 6 and 7 correspond to Liv-MIH-1 induced with $2 \%$ $\mathrm{MeOH}$ : Lane 6, day 1; Lane 7, day 2. Lanes 8 and 9 correspond to Liv-MIH-1 induced with $4 \% \mathrm{MeOH}$ : Lane 8, day 1; Lane 9, day 2. using the semidry blotting technique (Sambrook and Russell, 2001). Immunodetection was performed with an anti-myc-HRP antibody (Invitrogen). The membrane was soaked for $3 \mathrm{hrs}$ at room temperature in PBST $(137 \mathrm{mM}$ $\mathrm{NaCl}, 2.7 \mathrm{mM} \mathrm{KCl}, 10 \mathrm{mM} \mathrm{Na} 2 \mathrm{HPO}_{4}, 1.8 \mathrm{mM} \mathrm{KH}_{2} \mathrm{PO}_{4}$, $0.05 \%(\mathrm{v} / \mathrm{v})$ Tween-20, $\mathrm{pH} 7.4)$ with $5 \%(\mathrm{w} / \mathrm{v})$ nonfat milk powder (Svelty), and continued for $2 \mathrm{hrs}$ at room temperature in PBST containing $1 \%(\mathrm{w} / \mathrm{v})$ nonfat milk powder and the anti-myc-HRP antibody (1:3500 dilution). The membrane was washed four times for 15 min with PBST. The signal was detected using Enhanced Chemiluminescence (ECL) reagents (Amersham Biosciences, Piscataway, NJ, USA).

\section{Affinity-purification and $\mathrm{N}$-terminal sequencing}

The recombinant Liv-MIH-1 was purified by a Nickelcharged affinity column under native conditions according to the protocol of the ProBond Purification System (Invitrogen). Briefly, the supernatant from $50 \mathrm{ml}$ of induced cell culture was adjusted to $\mathrm{pH} 8.0$ and cleared by centrifugation at $3000 \mathrm{xg}$ for $10 \mathrm{~min}$. The supernatant was loaded onto a column $(10 \mathrm{ml})$ containing $1 \mathrm{ml}$ of ProBond Nickel-Chelating resin pre-equilibrated with the binding buffer $\left(50 \mathrm{mM} \mathrm{NaH} \mathrm{PO}_{4}, 500 \mathrm{mM} \mathrm{NaCl}, \mathrm{pH}\right.$ 8.0). The protein-bound resin was serially washed six times with native washing buffer $(20 \mathrm{mM}$ Imidazole, $50 \mathrm{mM}$ $\mathrm{NaH}_{2} \mathrm{PO}_{4}, 500 \mathrm{mM} \mathrm{NaCl}, \mathrm{pH} 8.0$ ). The protein was serially eluted 3 times in elution buffer $(250 \mathrm{mM}$ Imidazole, $50 \mathrm{mM}$ $\mathrm{NaH}_{2} \mathrm{PO}_{4}, 500 \mathrm{mM} \mathrm{NaCl}, \mathrm{pH}$ 8.0). Fractions were analyzed by Tricine-PAGE and their concentration was determined with the BCA Protein Assay Kit (Pierce, Rockford, IL, USA). The remainder of the eluted protein was concentrated using a $10 \mathrm{kDa}$ cut-off concentrator (Orbital Biosciences, Topsfiel, MA, USA) and stored at $-80^{\circ} \mathrm{C}$ until use.

$\mathrm{N}$-terminal sequencing was performed using affinity purified proteins blotted onto $0.45 \mu \mathrm{m}$ BioTrace PVDF membrane (Pall, Ann Arbor, MI, USA) after separation by Tricine-SDS-PAGE as previously described. The protein bands were excised from the membrane and analyzed using 


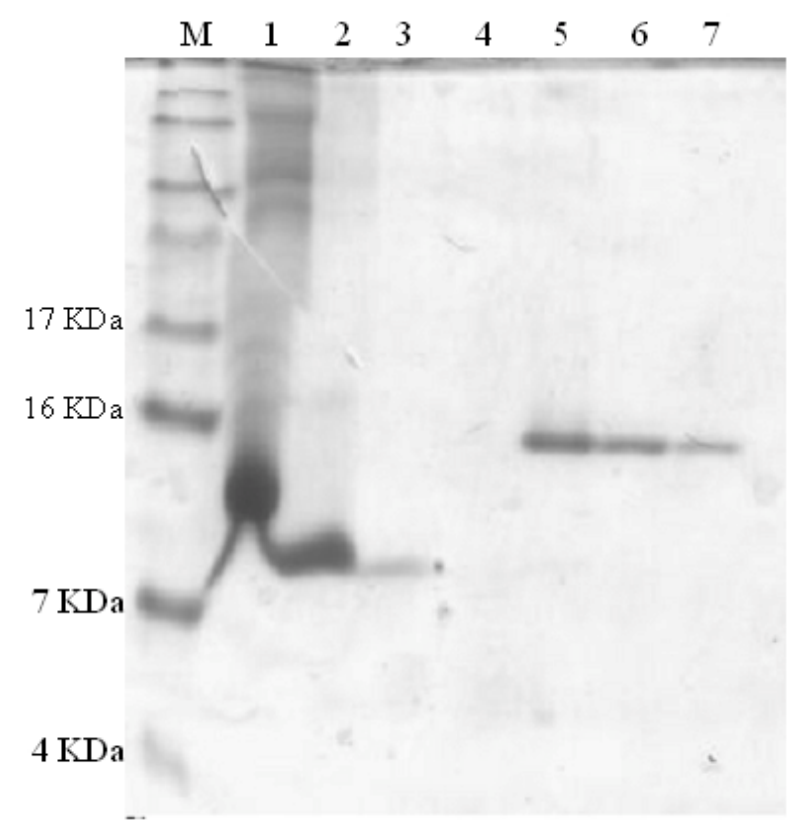

Figure 5. Analysis of affinity-purified recombinant Liv-MIH-1 protein by Coomassie-stained-Tricine-SDS-PAGE. M: SeeBlue Pre-Stained Standard (Invitrogen). Lane 1 corresponds to the non-purified protein; Lanes 2 to 4 correspond to the samples obtained from the first three serial washes of the protein-bound resin; Lanes 5 to 7 correspond to the three serial elutions of Liv-MIH-1.

Edman degradation (Procise 491 Protein Sequencing System; Applied Biosystems, Foster City, CA, USA).

\section{C-terminal removal}

Purified recombinant Liv-MIH-1 $(20 \mu \mathrm{g})$ was incubated overnight at $4^{\circ} \mathrm{C}$ with $0.1, \quad 0.5$ and $1.0 \quad \mathrm{U}$ of EnterokinaseMax (Invitrogen), as specified by the manufacturer, to remove the $c$-myc epitope and the $6 \mathrm{xHis}$ tag at the $\mathrm{C}$-terminus. A portion of the recombinant protein was similarly incubated with EnterokinaseMax buffer alone as a control. The enterokinase-treated Liv-MIH-1 recombinant protein was analyzed by Tricine-SDS-PAGE (16.5\%) followed by staining with Coomassie Brilliant Blue R-250.

\section{Bioassay for hyperglycemic activity}

Juvenile L. vannamei white shrimp $(18.4 \pm 6.1 \mathrm{~g})$ were maintained in individual containers $(5 \mathrm{~L})$ that were submerged in tanks with running seawater at $26^{\circ} \mathrm{C}$ and $34 \%$ salinity. The animals were fed daily with a commercial diet. Individual shrimp were allowed to molt once before they were unilaterally ablated by cutting and cauterizing the eyestalk on the third day after molting. Individual shrimp that were starved for $12 \mathrm{hrs}$ were injected with $2 \mu \mathrm{g}$ of recombinant Liv-MIH-1 dissolved in $100 \mu \mathrm{l}$ of PBS through the arthropodal membrane of the fifth walking leg by a syringe. For negative and positive controls groups, 100 $\mu 1$ of PBS and $100 \mu 1$ of 1 eyestalk's neuron equivalent crude extract on PBS was injected, respectively.

For glucose measurements, hemolymph $(100 \mu \mathrm{l})$ was removed from the pleopod base of the first abdominal segment just prior to injection (baseline) and $1 \mathrm{hr}$ after injection using a syringe with $200 \mu \mathrm{l}$ of anticoagulant solution (10 mM EDTA, $450 \mathrm{mM} \mathrm{NaCl}, 10 \mathrm{mM} \mathrm{KCl}, 10$ $\mathrm{mM}$ HEPES, pH 7.3) (Vargas-Albores et al. 1993). Hemolymph glucose concentrations were determined using a glucose oxidase diagnostic kit (Eagle Diagnostic, De Soto, TX, USA). Hyperglycemic activity was assessed by measuring the increase in hemolymph glucose levels following injection. The data were tested for homogeneity of variances and normality (Zar, 1999). Statistical analysis of the data was performed using one-way ANOVA.

\section{Bioassay for molt-inhibiting activity}

Thirty juvenile shrimp $(16.2 \pm 1.3 \mathrm{~g})$ were divided into three groups of 10 organisms each, and they were maintained using the same culture conditions as described for the hyperglycemic assay. On the third day after the first molt, individual shrimp were injected with $2 \mu \mathrm{g}$ of recombinant Liv-MIH-1 dissolved in $100 \mu 1$ of PBS through the arthropodal membrane of the fifth walking leg using a syringe. The shrimp in the control group were injected with $100 \mu \mathrm{l}$ of PBS. A second control group comprising uninjected shrimp was included. Shrimp were inspected daily for mortality and molting. The duration of the molt cycle was recorded. Statistical analysis of the data was performed using one-way ANOVA.

\section{RESULTS AND DISCUSSION}

\section{Construction of the $P$. pastoris expression vector containing Liv-MIH-1}

For the construction of the pPICZ $\alpha$ A-Liv-MIH-1 recombinant plasmid, Liv-MIH-1 cDNA from the pBADMIH expression vector was subcloned into the pPICZ $\alpha A$ vector using R2 and F2 primers (Figure 1). No mutations were found in the nucleotide sequence of the inserted fragment. The mature MIH peptide sequence was inserted in frame with the $\alpha$-factor protein secretion signal and the C-terminal recognition sites. The DNA sequence of the pPICZ $\alpha$ A-Liv-MIH-1 vector predicts that the recombinant protein will contain 101 amino acids: 73 amino acids in the mature MIH peptide and the remaining 28 amino acids comprising the enterokinase recognition site, $c$-myc epitope, and 6XHis tag (Figure 2). The expected molecular weight of the recombinant product is $12.1 \mathrm{kDa}$.

Approximately 30 transformants of the KM71 strain were generated. Twenty clones were isolated and ten of them were screened by PCR. All of the clones contained the expected 750 bp DNA fragment, indicating that the LivMIH-1 gene was integrated into the P. pastoris genome. 
Table 1. Molt cycle duration in the white shrimp $L$. vannamei after injection of recombinant Liv-MIH-1, PBS and uninjected. Duration was expressed as days \pm SD. Statistical analysis was performed by one-way ANOVA $(p=0.7)$.

\begin{tabular}{|c|c|c|}
\hline Group & Number (n) & Duration (days) \\
\hline Liv-MIH-1 $(2 \mu \mathrm{g})$ & 10 & $14.8 \pm 1.3$ \\
\hline PBS & 10 & $14.8 \pm 1.3$ \\
\hline Uninjected & 10 & $15.2 \pm 1.2$ \\
\hline
\end{tabular}

\section{Liv-MIH-1 expression}

The recombinant Liv-MIH-1 was expressed and secreted into the culture medium. The peptide was analyzed by Tricine-SDS-PAGE and the band corresponding to the expected size $(12.1 \mathrm{kDa})$ was visible on the gel. This protein band was not detected in non-induced cultures $(0 \%$ $\mathrm{MeOH})$ or in the culture of the transformant harboring pPICZ $\alpha A$ only. The expression of the recombinant LivMIH-1 protein correlated with the induction time and $\mathrm{MeOH}$ concentration; induction with $4 \% \mathrm{MeOH}$ for 1 day was optimal. No remarkable differences were observed with a greater induction time (Figure 3). Western blot analysis using the anti-myc-HRP antibody confirmed that the band observed corresponds to the expected recombinant protein (Figure 4).

\section{Recombinant protein purification and sequencing}

All contaminating proteins were removed by affinity purification of Liv-MIH-1 (Figure 5). The final yield of the recombinant Liv-MIH-1, after purification, was $8.7 \mathrm{mg} / \mathrm{l}$ of culture medium. N-terminal sequencing revealed that the first five amino acid residues of the secreted recombinant protein were DTFDH, which were identical to the mature Liv-MIH-1 protein. This confirmed that the $\alpha$-factor prepro-sequence of Liv-MIH-1 was successfully cleaved by the Kex2 protease without Glu-Ala repeats. Although the presence of Glu-Ala repeats enhances the activity of the Kex 2 protease when the $\alpha$-factor secretion signal is used, the subsequent processing of these repeats by the Ste 13 aminopeptidase is inefficient in some cases, resulting in extra amino acid residues in the recombinant protein (Briand et al. 1999; Raemaekers et al. 1999). The correct processing of the $\alpha$-factor without Glu-Ala repeats has been also shown in other previous studies (Briand et al. 1999; Raemaekers et al. 1999; Treerattrakool et al. 2002). The correct processing of the $\alpha$-factor prepro-sequence at the $\mathrm{N}$ terminus may be important for the correct folding and biological activity of the recombinant Liv-MIH-1 protein (Gong and Clark-Lewis, 1995). However, the presence of 20 additional amino acids in the N-terminus of the recombinant $\mathrm{CHH}$ from Metapenaeus ensis had no effect on the hyperglycemic activity (Gu et al. 2000).

\section{C-terminal removal}

Once the recombinant Liv-MIH-1 protein was purified by an affinity column using the $6 \mathrm{xHis}$ tag and the band was confirmed by the anti-myc-HRP antibody directed at the $c$ myc epitope, different concentrations of the enterokinase enzyme were used to remove the c-myc epitope and the 6xHis tag from the C-terminus of Liv-MIH-1. As can be observed in Figure 6, partial digestion products were obtained with all the enterokinase treatments. However, the digestion clearly allowed to distinguish the 22 amino acids fragment that was removed from the C-terminus of the recombinant protein, leaving the 6 amino acids of the enterokinase recognition site (Figure 2). This suggests a high specific cleavage site recognized by enterokinase. Enterokinase cleavage could be useful for recombinant proteins in which the His tag and the c-myc epitope of the C-terminus interfere with the biological activity of the proteins.

\section{Biological assay of recombinant Liv-MIH-1}

The hyperglycemic effect of injection with PBS, eyestalk extract, and recombinant Liv-MIH-1 on the hemolymph of unilaterally ablated L. vannamei was recorded $1 \mathrm{hr}$ after injection (Figure 7). In shrimp that were injected with recombinant Liv-MIH-1, an increase in hemolymph glucose level was detected $\left(12.9 \mathrm{mg} \cdot \mathrm{dl}^{-1}\right)$. This level was lower than that of shrimp that were injected with eyestalk

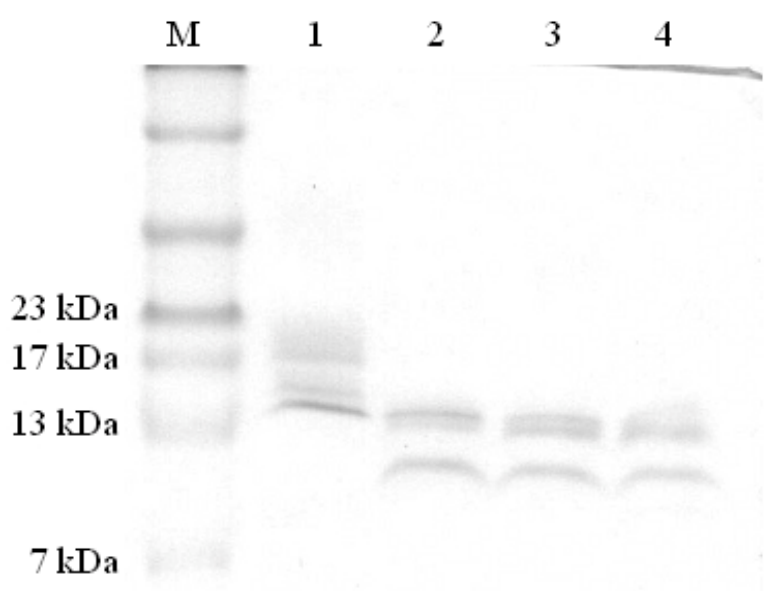

$4 \mathrm{kDa}$

Figure 6. Analysis of enterokinase-treated Liv-MIH-1 recombinant protein by Coomassie-stained-Tricine-SDSPAGE. M: MultiMark Multicolored Standard (Invitrogen). Lane 1 corresponds to the undigested purified protein; Lanes 2 to 4 correspond to the purified protein digested with enterokinase: Lane 2, $0.1 \mathrm{U}$; Lane 3, $0.5 \mathrm{U}$ and Lane 4, $1 \mathrm{U}$. 
extract $\left(19.7 \mathrm{mg} \cdot \mathrm{dl}^{-1}\right)$ but higher than PBS-injected shrimp $\left(4.7 \mathrm{mg} \cdot \mathrm{dl}^{-1}\right)(p<0.001)$.

The ability of recombinant Liv-MIH-1 to elevate glucose levels in the hemolymph of $L$. vannamei clearly indicates that the recombinant Liv-MIH-1 has hyperglycemic activity. This model is consistent with the primary structure of Liv-MIH-1 and its precursor -i.e., the lack of glycine at position 12 of the mature peptide compared with those of the $\mathrm{MIH} / \mathrm{GIH}$ group; the presence of a $\mathrm{CHH}$ precursorrelated peptide (CPRP) and the presence of the motif A1 (Lago-Lestón et al. 2007). All of these characteristics have been described for type I peptides of the $\mathrm{CHH}$ family (de Kleijn and van Herp, 1995; Lacombe et al. 1999; Böcking et al. 2001) and are in agreement with the high sequence similarity of other $\mathrm{CHH}$ neuropeptides that was documented in a phylogenetic analysis by Lago-Lestón et al. (2007). Interestingly, the analysis of the nucleotide sequence of Liv-MIH-1 and Liv-MIH-2 isoforms suggested that the mih gene from L. vannamei consist of 4 exons and 3 introns (Lago-Lestón et al. 2007). This exon structure is in agreement with the 4-exon organization observed in chh genes (type I) of a wide range of crustaceans and hexapods. Meanwhile, the 3-exon structure has been found in $\mathrm{mih} / \mathrm{gih}$ genes (type II) of crustacean species (Chen et al. 2005).

Furthermore, high gene expression levels of Liv-MIH-1 have been observed under extreme conditions of salinity (between 10\%o and 40\%) (Lago-Lestón et al. 2007). At this range of salinity, shrimp require active processes to compensate for changes in internal osmotic concentration (Díaz et al. 2001). In this regard, the hyperglycemic activity that was observed with Liv-MIH-1 concurs with the role of $\mathrm{CHH}$ in other processes such as osmoregulation (Serrano et al. 2003).

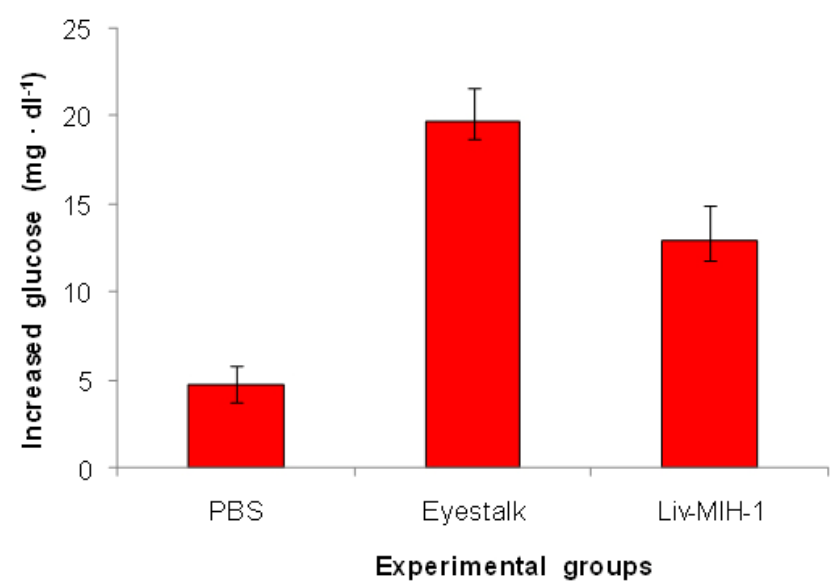

Figure 7. Increased glucose level in the hemolymph of unilaterally ablated $L$. vannamei at $1 \mathrm{hr}$ after injection with PBS, crude extract from one eyestalk and $2 \mu \mathrm{gg}$ of recombinant Liv-MIH-1. Results are expressed as the mean \pm SD. Statistical analysis was performed by one-way ANOVA ( $p<$ 0.001).
That the hyperglycemic effect of the recombinant protein was not comparable with that of the crude eyestalk extract can be explained by the presence of 22 additional amino acids in the $\mathrm{C}$-terminus, corresponding to the enterokinase recognition site, the c-myc epitope and the 6xHis tag. Additionally, the lack of carboxy-terminal amidation can also affect the biological activity of recombinant proteins. However, recombinant $M$. ensis $\mathrm{CHH}$ molecules (rMeCHH-A and rMeCHH-B), which have 27 additional amino acid residues at the N-terminus and a free $\mathrm{C}$ terminus, show hyperglycemic activity that is similar to that observed for crude eyestalk extracts (Gu et al. 2000). In contrast, low hyperglycemic activity was showed by recombinant $P$. japonicus CHH (rPej-SGP-I), which has 26 additional amino acid residues at the $\mathrm{N}$-terminus and an amidated C-terminus (Katayama et al. 2002). The authors also suggested that in addition to the $\mathrm{C}$-terminal amide moiety, the amino acid sequence at the C-terminus may be necessary for conferring hyperglycemic activity.

In our study, the moderate hyperglycemic activity that was elicited by recombinant MIH-Liv-1 may be ascribed to the extra amino acids at the C-terminus, which can partially affect MIH-Liv-1 activity. It is possible, then, that the $\mathrm{CHH}$ activity of Liv-MIH-1 would be improved after removing the His tag and c-myc epitope from the C-terminal region of the recombinant peptide through enzymatic cleavage by enterokinase.

The inhibiting effect of Liv-MIH-1 on molting was also studied in vivo in non-ablated $L$. vannamei shrimp. The molt cycle duration of shrimp that were injected with recombinant Liv-MIH-1 was similar to the control (PBS) and uninjected groups (Table 1); no statistical differences were detected by one-way ANOVA $(p=0.7)$. Because the molt cycle duration of Liv-MIH-1-injected shrimp was not longer than in control groups, recombinant Liv-MIH-1 may have not an inhibiting effect on molting.

In a similar bioassay using $1 \mu \mathrm{g}$ of recombinant $M$. ensis $\mathrm{MIH}$, which has extra amino acids at its N-terminus, the molt cycle duration was extended, and molt-inhibiting activity was proposed for this recombinant peptide ( $\mathrm{Gu}$ et al. 2001). These results suggest that extra amino acids at the $\mathrm{N}$-terminus are not critical for the MIH activity, but we can not discard the possibility that the extra amino acids at the C-terminus of Liv-MIH-1 could affect the conformation of the protein or the accessibility to the functional MIH site.

The structure of Marsupenaeus japonicus MIH consists of five $\alpha$-helices and no $\beta$-structures (Katayama et al. 2003). The functional site of MIH is located in a region that contains the C-terminal sides of the $\alpha 1$ and $\alpha 5$ helices (Katayama et al. 2004), which suggests that the extra amino acids in Liv-MIH-1 could be affecting MIH activity. An assay that examines Liv-MIH-1 without its extra amino acids should clarify whether Liv-MIH-1 has or does not have molt-inhibiting activity. Because $\mathrm{CHH}$ activity triggers important events in physiological processes, such 
as carbohydrate and lipid metabolism, reproduction, and osmoregulation, recombinant Liv-MIH-1 will facilitate studies on the physiological roles and structure-activity relationships in the eyestalk neurohormones of $L$. vannamei.

Previously we showed that sinus gland Liv-MIH-1 and Liv$\mathrm{MIH}-2$ are more related to the $\mathrm{CHH}$ group that to the $\mathrm{MIH} / \mathrm{GIH} / \mathrm{MOIH}$ group (Lago-Lestón et al. 2007). We now show that the recombinant Liv-MIH-1 had hyperglycemic activity so we propose to rename the protein Liv-CHHSG1, and Liv-MIH-2 as Liv-CHH-SG2. This will avoid confusion with the Liv-MIH-1 and Liv-MIH1 peptides reported by Chen et al (2007), which were also obtained from the eyestalk ganglia of L. vannamei, but belong to the $\mathrm{MIH} / \mathrm{GIH} / \mathrm{MOIH}$ group and function as MIHs.

\section{ACKNOWLEDGMENTS}

We thank Dr. Alexei F. Licea Navarro for his helpful comments and suggestions for this paper.

\section{REFERENCES}

BÖCKING, D.; DIRCKSEN, H. and KELLER, R. The crustacean neuropeptides of the CHH/MIH/GIH family: structure and biological activities. In: WIESE, K. ed. The crustacean nervous system. New York, NY., Springer Verlag, 2001, p. 84-97.

BRIAND, L.; PEREZ, V.; HUET, J.C.; DANTY, E.; MASSON, C. and PERNOLLET, J.C. Optimization of the production of a honeybee odorant-binding protein by Pichia pastoris. Protein Expression and Purification, April 1999, vol. 15, no. 3, p. 362-369.

CEREGHINO, J.L. and GREGG, J.M. Heterologous protein expression in the methylotrophic yeast Pichia pastoris. FEMS Microbiology Reviews, January 2000, vol. 24, no. 1, p. 45-66.

CHANG, E.S.; PRESTWICH, G.D. and BRUCE, M.J. Amino acid sequence of a peptide with both molt-inhibiting and hyperglycemic activities in the lobster, Homarus americanus. Biochemical and Biophysical Research Communications, September 1990, vol. 171, no. 2, p. 818826.

CHEN, H.-Y.; WATSON, R.D.; CHEN, J.-C.; LIU, H.-F. and LEE, C.-Y. Molecular characterization and gene expression pattern of two putative molt-inhibiting hormones from Litopenaeus vannamei. General and Comparative Endocrinology, March 2007, vol. 151, no. 1, p. $72-81$.

CHEN, S.H.; LIN, C.Y. and KUO, C.M. In silico analysis of crustacean hyperglycemic hormone family. Marine Biotechnology, June 2005, vol. 7, no. 3, p. 193-206.
DE KLEIJN, D.P.V. and VAN HERP, F. Molecular biology of neurohormone precursors in the eyestalk of Crustacea. Comparative Biochemistry and Physiology Part B: Biochemistry \& Molecular Biology, December 1995, vol. 112, no. 4, p. 573-579.

DIAZ, F.; FARFAN, C.; SIERRA, E. and RE, A.D. Effects of temperature and salinity fluctuation on the ammonium excretion and osmoregulation of juveniles of Penaeus vannamei, Boone. Marine Freshwater Behaviour Physiology, 2001, vol. 34, p. 93-104.

GONG, J.H. and CLARK-LEWIS, I. Antagonist of monocyte chemoattractant protein 1 identified by modification of functionally critical $\mathrm{NH}_{2}$-terminal residues. The Journal of Experimental Medicine, February 1995, vol. 181, p. 631-640.

GU, P.-L.; YU, K.L. and CHAN, S.-M. Molecular characterization of an additional shrimp hyperglycemic hormone: cDNA cloning, gene organization, expression and biological assay of recombinant proteins. FEBS Letters, April 2000, vol. 472, no. 1, p. 122-128.

GU, P.-L.; CHU, K.H. and CHAN, S.-M. Bacterial expression of the shrimp molt-inhibiting hormone (MIH): antibody production, immunocytochemical study and biological assay. Cell and Tissue Research, January 2001, vol. 303, no. 1, p. 129-136.

GU, P.-L.; TOBE, S.S.; CHOW, B.K.C.; CHU, K.H.; HE, J.-G. and CHAN, S.-M. Characterization of an additional molt inhibiting hormone-like neuropeptide from the shrimp Metapenaeus ensis. Peptides, November 2002, vol. 23, no. 11, p. 1875-1883.

KATAYAMA, H.; OHIRA, T.; AIDA, K. and NAGASAWA, H. Significance of a carboxyl-terminal amide moiety in the folding and biological activity of crustacean hyperglycemic hormone. Peptides, September 2002, vol. 23, no. 9, p. 1537-1546.

KATAYAMA, H.; NAGATA, K.; OHIRA, T.; YUMOTO, F.; TANOKURA, M. and NAGASAWA, $\mathrm{H}$. The solution structure of molt-inhibiting hormone from the kuruma prawn Marsupenaeus japonicus. The Journal of Biological Chemistry, March 2003, vol. 278, no. 11, p. 9620-9623.

KATAYAMA, H.; OHIRA, T.; NAGATA, K. and NAGASAWA, H. Structure-activity relationship of crustacean molt-inhibiting hormone from the kuruma prawn Marsupenaeus japonicus. Biochemistry, August 2004, vol. 43, no. 30 , p. $9629-9635$.

KHAYAT, M.; YANG, W-J.; AIDA, K.; NAGASAWA, H.; TIETZ, A.; FUNKENSTEIN, B. and LUBZENS, E. Hyperglycemic hormones inhibit protein and mRNA synthesis in in vitro- incubated ovarian fragments of marine shrimp Penaeus semisulcatus. General Comparative Endocrinology, June 1998, vol. 110, no. 3, p. 307-318. 
LACOMBE, C.; GRÈVE, P. and MARTÍN G. Overview on the sub-grouping of the crustacean hyperglycemic hormone family. Neuropeptides, February 1999, vol. 33, no. 1, p. 7180.

LAGO-LESTÓN, A.; PONCE, E. and MUÑOZ, M.E. Cloning and expression of hyperglycemic $(\mathrm{CHH})$ and moltinhibiting (MIH) hormones mRNAs from the eyestalk of shrimps of Litopenaeus vannamei grown in different temperature and salinity conditions. Aquaculture, September 2007, vol. 270, no. 1-4, p. 343-357.

OHIRA, T.; NISHIMURA, T.; SONOBE, H.; OKUNO, A.; WATANABE, T.; NAGASAWA, H.; KAWAZOE, I. and AIDA, K. Expression of a recombinant molting-inhibiting hormone of the kuruma prawn Penaeus japonicus in Escherichia coli. Bioscience, Biotechnology and Biochemistry, September 1999, vol. 63, no. 9, p. 15761581.

RAEMAEKERS, R.J.M.; DE MURO, L.; GATEHOUSE, J.A. and FORDHAM-SKELTON, A.P. Functional phytohemagglutinin (PHA) and Galanthus nivalis agglutinin (GNA) expressed in Pichia pastoris. Correct Nterminal processing and secretion of heterologous proteins expressed using the PHA-E signal peptide. European Journal of Biochemistry, October 1999, vol. 265, no. 1, p. 394-403.

SAMBROOK, J. and RUSSELL, D.V. Molecular cloning, a laboratory manual. $3^{\text {rd }}$ ed. Cold Spring Harbor, Cold Spring Harbor Laboratory Press, 2001. 2344 p. ISBN 978087969577-4.

SANTOS, E.A.; NERY, L.E.; KELLER, R. and GONÇALVES, A.A. Evidence for the involvement of crustacean hyperglycemic hormone in the regulation of lipid metabolism. Physiological and Biochemical Zoology, July-August 1997, vol. 70, no. 4, p. 415-420.

SCHÄGGER, H. Tricine-SDS-PAGE. Nature Protocols. May 2006, vol. 1, no. 1, p. 16-22.

SEFIANI, M.; LE CAER, J.P. and SOYEZ, D. Characterization of hyperglycemic and molt-inhibiting activity from sinus glands of the penaeid shrimp Penaeus vannamei. General and Comparative Endocrinology, July 1996, vol. 103, no. 1, p. 41-53.

SERRANO, L.; BLANVILLAIN, G.; SOYEZ, D.; CHAIRMANTIER, G.; GROUSSET, E.; AUJOULAT, F. and SPANINGS-PIERROT, C. Putative involvement of crustacean hyperglycemic hormone isoforms in the neuroendocrine mediation of osmoregulation in the crayfish Astacus leptodatylus. Journal of Experimental Biology, March 2003, vol. 206, no. 6, p. 979-988.

SONOBE, H.; NISHIMURA, T.; SONOBE, M.; NAKATSUJI, T.; YANAGIHARA, R.; KAWAKAMI, T. and AIMOTO S. The molt-inhibiting hormone in the
American crayfish Procambarus clarkii: its chemical synthesis and biological activity. General and Comparative Endocrinology, February 2001, vol. 121, no. 2, p. 196-204.

SUN, P.S. Molecular cloning and sequence analysis of a cDNA encoding a molt-inhibiting hormone-like neuropeptide from the white shrimp Penaeus vannamei. Molecular Marine Biology and Biotechnology, February 1994, vol. 3, no. 1, p. 1-6.

SUN, P.S. Recombinant molt-inhibiting hormone-like neuropeptide produced in the yeast Pichia pastoris. In: Pacon 97 Proceedings. Symposium on Resource Development. $\left(6^{\text {th }}-8^{\text {th }}\right.$ August, 1997, Hong Kong, China). p. 509-518.

TREERATTRAKOOL， S.; EURWILAICHITR, L.; UDOMKIT, A. and SAKOL, P. Secretion of Pem-CMG, a peptide in the CHH/MIH/GIH family of Penaeus monodon, in Pichia pastoris is directed by secretion signal of $\alpha$ mating factor from Saccharomyces cerevisiae. Journal of Biochemistry and Molecular Biology, September 2002, vol. 35 , no. 5 , p. $476-481$.

UDOMKIT, A.; TREERATTRAKOOL, S. and SAKOL, P. Crustacean hyperglycemic hormone of Penaeus monodon: cloning, production of active recombinant hormones and their expression in various shrimp tissues. Journal of Experimental Marine Biology and Ecology, January 2004, vol. 298, no. 1, p. 79-91.

VARGAS-ALBORES, F.; GUZMAN, M.A. and OCHOA, J.L. An anticoagulant solution for haemolymph collection and prophenoloxidase studies of penaeid shrimp (Penaeus californiensis). Comparative Biochemistry and Physiology Part A: Physiology, October 1993, vol. 106, no. 2, p. 299303.

WEBSTER, S.G. and CHUNG, J.S. Roles of moultinginhibiting hormone and crustacean hyperglycemic hormone in controlling moulting in decapods crustaceans. In: ROUBOS E.W.; WENDELAAR BONGA, S.E.; VAUDRY $\mathrm{H}$. and DE LOOF, A. eds. Recent developments in comparative endocrinology and neurobiology. Maatricht, Shaker Publishing P.V., 1999, p. 213-216.

YASUDA, A.; YASUDA, Y.; FUJITA, T. and NAYA, Y. Characterization of crustacean hyperglycemic hormone from the crayfish (Procambarus clarkii); multiplicity of molecular forms by stereoinversion and diverse functions. General and Comparative Endocrinology, September 1994, vol. 95 , no. 3, p. 387-398.

YODMUANG, S.; UDOMKIT, A.; TREERATTRAKOOL, S. and SAKOL, P. Molecular and biological characterization of molt-inhibiting hormone of Penaeus monodon. Journal of Experimental Marine Biology and Ecology, November 2004, vol. 312, no. 1, p. 101-114. 